Ege Tıp Dergisi / Ege Journal of Medicine 2020; 59 (3): 174-180

\title{
Yoğun bakım hastalarında serum CRP düzeylerinin sepsis değerlendirmesindeki yeri
}

Evaluation of serum CRP levels in patients with sepsis at intensive care unit

Cem Ece ${ }^{1}$ (1D

Kubilay Demirağ ${ }^{2} \mathbb{D}$

\author{
İlkin Çankayali ${ }^{2}$
}

Mehmet Uyar ${ }^{2}$ (D)
Canan Bor $^{3}$ ic

Ali Reşat Moral ${ }^{4}$ [D

${ }^{1}$ İzmir Tınaztepe Üniversitesi, Galen Hastanesi Anesteziyoloji ve Reanimasyon Kliniği, İzmir, Türkiye

${ }^{2}$ Ege Üniversitesi Tıp Fakültesi Anesteziyoloji ve Reanimasyon Anabilim Dalı, Yoğun Bakım BD, İzmir, Türkiye

${ }^{3}$ Ege Üniversitesi Tıp Fakültesi Anesteziyoloji ve Reanimasyon Anabilim Dalı, İzmir, Türkiye

${ }^{4}$ Özel Kent Hastanesi Anesteziyoloji ve Reanimasyon Kliniği, İzmir, Türkiye

Öz

Amaç: Sepsiste meydana gelen inflamatuar yanıt, prognoz göstergesi olabilen biyobelirteçlerin salınımına neden olmaktadır. Çalışmamızda yoğun bakım kliniğinde 30 gün ve daha az süre yatan hastalarda CRP, PCT, Laktat düzeyleri ve SOFA Skoru değişimleri ile bunların prognoz tahminindeki yerinin değerlendirilmesi amaçlandı.

Gereç ve Yöntem: Anesteziyoloji ve Reanimasyon Anabilim Dalı Yoğun Bakım Kliniğinde yatarak tedavi gören 485 hasta randomize olarak çalışmaya dahil edildi ve dosya bilgileri retrospektif olarak incelendi. Hastaların yaş, cinsiyet, yoğun bakımda yatış süreleri, yoğun bakıma yatışta ve yoğun bakımda izlendikleri günlerdeki sepsis tanı kriterleri, serum CRP, PCT, laktat düzeyleri, SOFA ve APACHE II skorları kaydedildi. Hastaların yoğun bakımda yattıkları tüm günler için sepsis tanıları (sepsisin olmadığı dönem / sepsis / ağır sepsis / septik şok) 2001 konsensus ve 2008 Surviving Sepsis Campaign rehberine göre kondu.

Bulgular: Ortalama yaş $51,1 \pm 20,6$, ortalama APACHE II skoru ise $23,2 \pm 8,9$ olarak belirlendi. Hastaların 35'i yoğun bakımdan taburcu $(\% 7,21)$, 164'ü hastane içi diğer kliniğe sevk edilirken $(\% 33,82) 286$ hastada $(\% 58,97)$ eksitus gerçekleştiği görüldü. Hastaların 178'i yoğun bakım yatış süresince sepsis tanısı almadı. Hastaların 307'sinin ise sepsis, ağır sepsis ya da septik şok tanılarından biri ya da fazlasını aldığı saptandı.

Sepsis, ağır sepsis ve septik şok tanısı alan hastaların ortalama CRP değerleri sırasıyla 9,33, 13,76 ve $16,77 \mathrm{mg} / \mathrm{dl}$ olarak; PCT ortalama değerleri ise $1,66,5,23$ ve $12,42 \mathrm{ng} / \mathrm{ml}$ olarak bulundu.

Hastaların 35'i yoğun bakımdan taburcu $(\% 7,21)$, 164'ü diğer kliniğe sevk edilirken $(\% 33,82), 286$ hastada $(\% 58,97)$ eksitus gerçekleştiği görüldü. Eksitus olan grupta son CRP değerinin ilk ölçülen CRP değerine oranı; taburcu ve diğer kliniklere nakil olan gruba göre istatistiksel olarak yüksek bulundu.

Sonuç: Serum CRP düzeyinin sepsisin ciddiyetine paralel olarak arttığı ve sepsiste güvenilir bir prognostik faktör olduğu kanısına varıldı.

Anahtar Sözcükler: Sepsis, yoğun bakım, CRP.

\section{Abstract}

Aim: The inflammatory response that occurs in sepsis causes the release of biomarkers which may be prognostic indicators. In our study, it was aimed to evaluate the CRP, PCT, Lactate levels and SOFA score change and their effect on prognosis estimation of patients that were hospitalized 30 days or less.

\footnotetext{
Sorumlu yazar: Cem Ece

İzmir Tınaztepe Üniversitesi, Galen Hastanesi Anesteziyoloji

ve Reanimasyon Kliniği. İzmir, Türkiye

E-posta: cemece.dr@gmail.com

Başvuru Tarihi: 16.08.2019

Kabul Tarihi: 21.02.2020
} 
Materials and Methods: 485 patients who were hospitalized in the Anesthesiology and Reanimation ICU for 30 days or less were included in the study randomly and patient records were evaluated retrospectively. Age, gender, length of hospitalization in intensive care unit, sepsis diagnostic criteria on admission and intensive care unit days, serum CRP, PCT, lactate levels, SOFA and APACHE II scores were recorded. The diagnosis of sepsis (no sepsis / sepsis / severe sepsis / septic shock) was made according to the 2001 consensus and 2008 Surviving Sepsis Campaign guideline for all days in the intensive care unit.

Results: The mean age was $51.1 \pm 20.6$ years and the mean APACHE II score was $23.2 \pm 8.9$ years. 35 patients were discharged from intensive care unit (7.21\%), 164 patients were referred to other inhospital clinic (33.82\%) while 286 patients (58.97\%) died. 178 patients were never diagnosed as sepsis during intensive care stay. 307 of them were diagnosed as sepsis, severe sepsis or septic shock. In our study, the median CRP values of the patients with sepsis, severe sepsis and septic shock were 9.33, 13.76 and $16.77 \mathrm{mg} / \mathrm{dl}$, respectively; PCT median values were found to be 1.66, 5.23 and $12.42 \mathrm{ng} / \mathrm{ml}$. Thirty-five of the patients (7.21\%) were dismissed from the ICU, $164(33.82 \%)$ were transferred to other departments and 286 (58.97\%) were exitus. The ratio of the last CRP value measured to the first measured one in the exitus group was statistically significant compared to patients dismissed or transferred to other departments

Conclusion: It was concluded that CRP level increases with increasing severity of sepsis and it is a reliable prognostic parameter in sepsis.

Keywords: Sepsis, intensive care, CRP.

\section{Giriş}

Sepsis yoğun bakım hastalarında morbidite ve mortalitenin önemli nedenlerinden biridir. Enfeksiyona yanıt olarak disregüle/bozulmuş olan konak savunması nedeni ile gelişen hayatı tehdit eden organ disfonksiyonu olarak tanımlanmaktadır (1-4).

Bulgularının nonspesifik olması nedeniyle günümüze dek sepsisin tanımlaması, tanı kriterleri ve ileri tedavi rehberleri üzerinde konsensus toplantıları ve değişiklikler yapılmıştır (1).

Sepsiste genetik yatkınlığı olan konak ve etken mikroorganizma arasındaki etkileşim sonucunda oluşan inflamatuar yanıt, prognoz göstergesi olabilen biyo-belirteçlerin salınımına neden olmaktadır (5).

2016 yılında yapılan yeni sepsis tanımlamasında inflamatuvar belirteçlerin yer almadığı ancak 2017 yılında yayınlanan yeni rehberde sepsis yönetiminde önemini koruduğu görülmektedir.

C-reaktif protein (CRP) doku yaralanması veya enfeksiyona yanıt olarak IL-6 uyarısıyla karaciğerde üretilen bir akut faz proteinidir. CRP düzeyindeki artış enfeksiyonun klasik bir bulgusudur (6). Ancak enfeksiyon dışında travma, cerrahi, otoimmün hastalıklar kanser ve kronik inflamatuar hastalıklarda da artmasından dolayı mikrobiyal enfeksiyonu her zaman ayırt edemeye bilmektedir. CRP, infeksiyon geriledikten sonra birkaç gün hatta hafta yüksek kalabilmektedir.

Prokalsitonin (PCT), 116 aminoasitten oluşan, molekül ağırlığı yaklaşık olarak $13 \mathrm{kDa}$ olan bir proteindir. Viral infeksiyonlar ve inflamatuvar durumlarda $1,5 \mathrm{ng} / \mathrm{ml}$ düzeylerine çıkmaktadır. Öte yandan sistemik belirtilere yol açan ağır bakteriyel infeksiyonlarda ve inflamasyonda PCT düzeyi 100 ng/ml'nin üzerine çıkabilmektedir (6).

Yoğun bakıma yatış sırasında fizyolojiye dayalı skorlama sistemleri kullanılmaktadır. Akut Fizyoloji ve Kronik Sağlık Değerlendirmesi (Acute Physiology and Chronic Health Evaluation= APACHE), laboratuvar ve klinik değişiklikleri içeren değişkenlerin kullanıldığı ve hastalığın prognozu ve mortalite riski ile paralellik gösteren bir skorlama sistemidir.

Çalışmamızda yoğun bakım kliniğinde 30 gün ve daha az süre yatan hastalarda CRP, PCT, Laktat düzeyleri ve SOFA Skoru değişimleri ile bunların prognoz tahminindeki yerinin değerlendirilmesi amaçlandı.

\section{Gereç Yöntem}

Ege Üniversitesi Tıp Fakültesi etik kurulundan izin alındıktan sonra başlanılan çalışmada, Ege Üniversitesi Tıp Fakültesi Anesteziyoloji ve Reanimasyon Anabilim Dalı Yoğun Bakım Kliniğinde 01.01.2009-30.11.2010 tarihleri arasında yatarak tedavi gören 1045 hasta 
arasından, yoğun bakımda yatış süresi 30 gün ve altı olan 485 hasta, randomize olarak çalışmaya dahil edildi ve dosya bilgileri retrospektif olarak incelendi.

Çalışmaya dahil olan hastaların yaş, cinsiyet, yoğun bakımda yatış süreleri, yoğun bakıma yatışta ve yoğun bakımda izlendikleri günlerdeki sepsis tanı kriterleri, serum CRP, PCT, laktat düzeyleri, APACHE II skorları kaydedildi.

Değerlendirilmeye alınan hastaların yoğun bakımda yattığı tüm günler için CRP, PCT, laktat düzeylerindeki değişimlerini görmek amacıyla sepsisin evrelerindeki geçişe göre altı grup belirlendi.

Grup 1. Sepsis tanısı yok iken ilerleyen günlerde sepsis tanısı alan hastalar.

Grup 2. Sepsis tanısı yok iken ilerleyen günlerde ağır sepsis tanısı alan hastalar.

Grup 3. Sepsis tanısı yok iken ilerleyen günlerde septik şok tanısı alan hastalar.

Grup 4. Sepsis tanısı alan ve ilerleyen günlerde ağır sepsis tanısı alan hastalar.

Grup 5. Sepsis tanısı alan ve ilerleyen günlerde septik şok tanısı alan hastalar.

Grup 6. Ağır sepsis tanısı alan ve ilerleyen günlerde septik şok tanısı alan hastalar.

Hastaların yoğun bakımda yattığı tüm günler için sepsis tanıları (sepsisin olmadığı dönem, sepsis, ağır sepsis ve septik şok) 2001 konsensus ve 2008 Surviving Sepsis Campaign rehberine göre kondu. Hastaların tanı konulduktan sonraki ilk CRP, PCT ve laktat değerleri alındı ve her grup için kaydedildi. Ayrıca yoğun bakıma yatış ve çıkış esnasındaki serum CRP düzeylerinin oranları hesaplandı. SOFA (Sequential Organ Failure Assessment Score) skoru hesaplamasında kullanılan parametrelerin gün içindeki en kötü değerleri alındı. Parametrelerin çalışılmamış ya da izlem formunda belirtilmemiş olması durumunda ise bir gün önceki değerler alındı.

Çalışmanın sonunda elde edilen veriler Ege ÜTF Biyoistatistik ve Tıbbi Bilişim AD tarafından Wilcoxon Signed Ranks testi ile değerlendirildi. $p<0.05$ değerleri istatistiksel olarak anlamlı kabul edildi.

\section{Bulgular}

Çalışmaya 284'ü kadın 201'i erkek toplam 485 hasta alındı. Ortalama yaş $51,1 \pm 20,6$, ortalama
APACHE II skoru ise $23,2 \pm 8,9$ olarak belirlendi. Hastaların 35 'i yoğun bakımdan taburcu $(\% 7,21)$, 164'ü hastane içi diğer kliniğe sevk edilirken $(\% 33,82) \quad 286$ hastada $(\% 58,97)$ eksitus gerçekleştiği görüldü (Tablo-1).

Hastaların 178'i yoğun bakım yatış süresince hiçbir dönem sepsis tanısı almadı. Üç yüz yedisinin (307) ise yatış süresi boyunca sepsis, ağır sepsis ya da septik şok tanılarından en az birisini aldığı saptandı (Tablo-2).

Yoğun bakıma yatış esnasında sepsisi olmayan hastalarda yoğun bakımdan taburculuk oranı $\% 12,6$, diğer kliniklere nakil oranı ise \%46 oranında saptandı. Yatış esnasında sepsisi olmayan hastalardaki taburculuk oranı diğer grupların taburculuk oranına göre istatistiksel olarak anlamlı yüksek bulundu ( $p<0,05$; Tablo-2).

Yoğun bakıma yatış esnasında septik şok tanısı alan hastalardaki eksitus oranı \%91,2 oranında saptandı. Bu oran diğer grupların eksitus oranlarına göre istatistiksel olarak anlamlı yüksek bulundu $(p<0,05$; Tablo-2).

Eksitus olan grupta son CRP değerinin ilk ölçülen CRP değerine oranı (CRP-SON/CRP-ILK) 1,52 saptandı. Bu oran taburcu ve diğer kliniklere nakil olan grubun oranlarına göre istatistiksel olarak yüksek bulundu ( $p<0,05$; Tablo-3).

Sepsis, ağır sepsis ve septik şok tanısı alan hastaların ortalama CRP değerleri sırasıyla 9,33, 13,76 ve $16,77 \mathrm{mg} / \mathrm{dl}$; ortalama PCT değerleri ise $1,66,5,23$ ve $12,42 \mathrm{ng} / \mathrm{ml}$ bulundu (Tablo-4).

Her bir grupta CRP, PCT, laktat düzeyleri ve SOFA skoru değişimlerine bakıldığında Grup 1'de laktat düzeylerindeki değişim dışında tüm gruplardaki değişimlerin istatistiksel olarak anlamlı olduğu görüldü. $(p<0,001 ;$ Tablo-5)

Gruplar arası CRP ve PCT düzeyleri değişimlerine bakıldığında Grup 1, Grup 2 ve Grup 3'te CRP-SON/CRP-ILK oranının Grup 6 ile karşılaştırıldığında istatistiksel olarak anlamlı olacak şekilde yüksek olduğu görüldü. Sepsisin farklı evrelerindeki CRP-SON/CRP-ILK oranları arasında istatistiksel olarak anlamlı fark bulunmadı. Grup 6 ile karşılaştırıldığında PCTSON/PCT-İLK oranının, Grup 3 ve Grup 4'te istatistiksel olarak anlamlı olacak şekilde yüksek olduğu görüldü (Tablo-6). 
Tablo-1. Hastalara ait genel veriler (ortıstandart sapma).

\begin{tabular}{ll}
\hline & Tüm Hastalar $(\mathbf{n}=\mathbf{4 8 5})$ \\
\hline Yaş (Yıl) & $51,14 \pm 20,60$ \\
Cinsiyet (E/K) & $284 / 201$ \\
APACHE II & $23,24 \pm 8,94$ \\
Yatış Süresi (Gün) & $4,76 \pm 4,23$ \\
Cerrahi Hasta (n=348) & $\% 71,76$ \\
Dahili Hasta ( $\mathbf{n}=137)$ & $\% 28,24$ \\
Çıkan (n=35) & $\% 7,21$ \\
Hastane İçi Nakil (n=164) & $\% 33,82$ \\
Eksitus (n=286) & $\% 58,97$ \\
\hline
\end{tabular}

Tablo-2. Hastaların yatış sırasındaki sepsis derecesi / sonuç ilişkisi ve yatış süresi boyunca herhangi bir dönem sepsis ve evreleri tanısı alma oranları ( $\mathrm{n} ; \%)$.

\begin{tabular}{lccc}
\hline Yatıştaki Sepsis Durumu & Eksitus & Taburcu & Diğer Kliniğe Nakil \\
\hline Sepsis olmayan $(n=215 ; \%)$ & $89 ; 41,4$ & $27 ; 12,6^{*}$ & $99 ; 46$ \\
Sepsis $(n=50 ; \%)$ & $17 ; 32,7$ & $3 ; 6,1$ & $30 ; 61,2$ \\
Ağır sepsis $(n=107 ; \%)$ & $77 ; 72$ & $4 ; 3,7$ & $26 ; 24,3$ \\
Septik şok $(n=113 ; \%)$ & $103 ; 91,2^{*}$ & $1 ; 0,9$ & $9 ; 8$ \\
\hline
\end{tabular}

${ }^{*} \mathrm{p}<0,05$

Tablo-3. CRP düzeyleri ve sonuç ile ilişkisi [ortalama (min.-maks.)].

\begin{tabular}{lccc}
\hline & Exitus olan grup & Taburcu olan grup & $\begin{array}{c}\text { Diğer Kliniğe Nakil olan } \\
\text { grup }\end{array}$ \\
\hline Yatıştaki CRP düzeyi $(\mathrm{mg} / \mathrm{dl})$ & $9,06(0,14-40,9)$ & $13,52(8,44-28,7)$ & 9,$67 ; 0,14-37,16$ \\
Çıkıştaki CRP düzeyi $(\mathrm{mg} / \mathrm{dl})$ & $16,52\left(1,4-46,2^{*}\right)$ & $4,93(1,4-14,1)$ & $6,62(0,54-41,86)$ \\
CRP oranı & $1,52\left(0,35-50,57^{\star}\right)$ & $0,28(0,16-0,97)$ & $0,99(0,09-117,43)$ \\
\hline
\end{tabular}

${ }^{*} p<0.05$

CRP: C-Reaktif Protein

Tablo-4. CRP, PCT, laktat ve SOFA skorlarının sepsis ve evrelerindeki değerleri [ortalama (min.-maks.)].

\begin{tabular}{|c|c|c|c|c|}
\hline & $\begin{array}{c}\text { Sepsis olmayan } \\
(n=250)\end{array}$ & $\begin{array}{l}\text { Sepsis } \\
(n=106)\end{array}$ & $\begin{array}{c}\text { A.sepsis } \\
(n=144)\end{array}$ & $\begin{array}{c}\text { S.şok } \\
(n=178)\end{array}$ \\
\hline CRP (mg/dl) & $2,6(0,1-43,5)$ & $9,33\left(0,27-35,76^{\star}\right)$ & $13,76(0,54-199 * / \#)$ & $16,77\left(1,56-48,1^{*} / * \star\right)$ \\
\hline PCT (ng/dl) & $0,49(0-19,6)$ & $1,66\left(0,02-465^{\star}\right)$ & $5,23\left(0,11-255,35^{\star} / \#\right)$ & $12,42\left(0,64-482,1^{* / * *}\right)$ \\
\hline LAKTAT (mmol/l) & $1,8(0,1-20,2)$ & $1(0,1-14)$ & $2,4(0,8-13,5$ */\#) & $4,6\left(0,4-20^{\star} / * \star\right)$ \\
\hline SOFA skoru & $4(0-22)$ & $4\left(0-18^{\star}\right)$ & $9\left(1-21^{\star} / \#\right)$ & $14\left(5-22^{* / *}\right)$ \\
\hline
\end{tabular}

${ }^{*} p<0,05$ sepsis olmayan grupla karşılaştırma

${ }^{* *} p<0,05$ septik şok, ağır sepsis karşılaştırması

$\# \mathrm{p}<0,05$ ağır sepsis, sepsis karşılaştırması

CRP: C-Reaktif Protein

PCT: Prokalsitonin

SOFA: Sequential Organ Failure Assessment 
Tablo-5. CRP, PCT, laktat düzeyleri ve SOFA skoru değişimleri [ortalama (min.-maks.)].

\begin{tabular}{|c|c|c|c|c|c|}
\hline & & CRP & РCT & Laktat düzeyi & SOFA skoru \\
\hline \multirow{2}{*}{ Grup $1(n=28)$} & Sepsis yok & $5.23(0,14-17,6)$ & $0,41(0,06-2,2)$ & $1,2(0,4-6,6)$ & $4(0-14)$ \\
\hline & Sepsis & $12.371\left(, 8-23,4^{\star}\right)$ & $1,2\left(0,09-465^{\star}\right)$ & $1,25(0,4-10)$ & $6,5\left(0-16^{\star}\right)$ \\
\hline \multirow{2}{*}{ Grup $2(n=17)$} & Sepsis yok & $5,41(0,13-17,6)$ & $0,68(0,06-5,2)$ & $1,3(0,8-10,7)$ & $7(0-18)$ \\
\hline & Ciddi Sepsis & $15,931\left(, 1-41,86^{\star}\right)$ & $4,18\left(0,40-13,38^{\star}\right)$ & $2,2\left(1,1-13,5^{\star}\right)$ & $10(1-20)^{*}$ \\
\hline \multirow{2}{*}{ Grup 3 (n=7) } & Sepsis yok & $4,3(2,04-14,3)$ & $1,73(0,14-5,2)$ & $1,6(0,8-5,6)$ & $8(5-12)$ \\
\hline & Septik şok & $18,83\left(14,8-27,17^{\star}\right)$ & $26,631\left(1,38-36,72^{\star}\right)$ & $2,4\left(1-4^{\star}\right)$ & $15(9-16)^{*}$ \\
\hline \multirow{2}{*}{ Grup $4(n=26)$} & Sepsis & $8,06(0,27-33,3)$ & $1,25(0,09-50,9)$ & $1(0,21-2,7)$ & $5,50(1-14)$ \\
\hline & Ciddi Sepsis & $16,44\left(4,94-41,86^{\star}\right)$ & $3,6\left(0,5-255,35^{\star}\right)$ & $1,91(1-11,40)^{*}$ & $10\left(1-16^{\star}\right)$ \\
\hline \multirow{2}{*}{ Grup 5 (n=9) } & Sepsis & $8,98(2,28-25,46)$ & $2,46(0,18-5)$ & $1(0,79-2,3)$ & $8(2-14)$ \\
\hline & Septik şok & $18,83\left(7,67-36,12^{\star}\right)$ & $35,2\left(2,54-46,72^{\star}\right)$ & $3,2\left(1-10,50^{\star}\right)$ & $14\left(0,8-20^{\star}\right)$ \\
\hline \multirow[b]{2}{*}{ Grup $6(n=66)$} & Ciddi Sepsis & $11,34(1,27-33,3)$ & $9(0,22-225)$ & $2,5(0,87-10,9)$ & $9(1-21)$ \\
\hline & Septik şok & $20,11\left(5,11-46,2^{\star}\right)$ & $\begin{array}{c}17,75(0,64- \\
\left.300,03^{*}\right)\end{array}$ & $3,8\left(0,80-16,17^{\star}\right)$ & $14\left(3-22^{*}\right.$ \\
\hline
\end{tabular}

${ }^{*} p<0.05$

CRP: C- Reaktif Protein

PCT: Prokalsitonin

SOFA: Sequential Organ Failure Assessment

Tablo-6. Gruplar arası CRP, PCT, laktat Düzeyleri ve SOFA skoru değişimleri (SON/ILK) [ortalama (min.-maks.)].

\begin{tabular}{|c|c|c|c|c|}
\hline & CRP & РCT & LAKTAT & SOFA \\
\hline Grup1 (n=28) & $2,23\left(1,04-75,29^{\star}\right)$ & $2,7(1-290,63)$ & $1,11(0,31-3,16)$ & $1,16(0-3)$ \\
\hline Grup $2(n=17)$ & $3,62\left(1,08-117,43^{*}\right)$ & $3,03(0,85-11,54)$ & $1,52\left(1-5,19^{\star}\right)$ & $1,5(0,75-3)$ \\
\hline Grup $3(n=7)$ & $4,23\left(1,43-9,23^{*}\right)$ & $7,06\left(6,58-10,05^{\star}\right)$ & $1,3(0,3-5)$ & $1,75(1,33-2,29)$ \\
\hline Grup $4(n=26)$ & $2,04(0,75-21,78)$ & $2,12\left(0,1-64,72^{\star}\right)$ & $1,95\left(0,6-5,75^{\star / * \star}\right)$ & $1,27(1-6)$ \\
\hline Grup $5(n=9)$ & $1,7(0,94-8,26)$ & $10,15(2,07-259,56)$ & $2,3\left(1-8,75^{*}\right)$ & $1,7\left(1,14-7^{\star / * \star \star}\right)$ \\
\hline Grup $6(n=66)$ & $1,69(0,71-13,46)$ & $1,65(0,16-82,64)$ & $1,33(0,3-5,91)$ & $1,33(0,6-1)$ \\
\hline
\end{tabular}

${ }^{*} p<0,05$ (Grup 6) ve ** $p<0,05$ (Grup 4-1) ${ }^{* * *} p<0,05$ (Grup 4-5)

CRP: C-Reaktif Protein

PCT: Prokalsitonin

SOFA: Sequential Organ Failure Assessment

\section{Tartışma}

CRP enfeksiyon/sepsise spesifik bir bulgu olmayıp tanı koyma yanında tedaviye yanıtın izlenmesinde de yaygın olarak kullanılan bir belirteçtir ve iyi bir klinik değerlendirmeyle birlikte yorumlanmalıdır. CRP sepsis konsensus kriterlerinde de yer alan bir parametredir (1-5). Sonuçlarımız gerek ilk kez sepsis tanısı alındığında gerekse sepsis derecesi artığında CRP, PCT düzeyleri ve SOFA skorlarında istatistiksel olarak anlamlı artışın olduğunu gösterdi. Yoğun bakıma yattığı anda sepsis tanısı olmayıp yatış süresince sepsis, ağır sepsis ve septik şok tanısı alan gruptaki hastalarda artış oranı sepsis evrelerindeki artış oranlarına göre daha yüksek bulundu.

Sepsis, ağır sepsis ve septik şok tanısı alan hastaların ortalama CRP düzeyleri sırasıyla 9,33, 13,76 ve $16,77 \mathrm{mg} / \mathrm{dl}$ olarak bulundu (Tablo-4). Sümer ve arkadaşlarının yaptıkları çalışmada sepsis tanılı grupta CRP düzeyi $139,5 \mathrm{mg} / \mathrm{dl}$ olarak saptanmış; CRP yanında PCT, IL-6, IL-8 ve endotoksin düzeylerinin de tedaviye yanıtın izleminde kullanılabileceği ileri sürülmüştür (6). Bu çalışmada ortalama CRP düzeyinin sepsisin hangi aşamasına ait olduğu belirtilmemektedir. Çalışmamızda ise bu çalışmadan farklı olarak sepsis, ağır sepsis ve septik şok tanısının 
konduğu sıradaki ilk düzeyler ve bunların değişimleri karşılaştırılmıştır.

Sepsisli yaşlı hastalarda prognoza etki eden faktörlerin araştırıldığı bir çalışmada eksitus olan gruptaki ortalama CRP düzeyi $18,42 \mathrm{mg} / \mathrm{dl}$, şifayla taburcu grupta ise $13,50 \mathrm{mg} / \mathrm{dl}$ olarak bulunmuştur (7). Bir diğer çalışmada ise Aks ve ark. (8) şiddetli sepsis ile başvuran erişkin hastaların mortalitesine etki eden faktörleri incelemişler ve CRP, laktat düzeyleri ve APACHE II ile SOFA skorlarının yüksek mortalite ile ilişkili değişkenler olarak belirlemişlerdir. Sepsis tanısı alan hastalarda SOFA skoru, lökosit sayısı, PCT ve IL-6 düzeylerinin 30 günlük mortaliteye etki eden belirteçler olabileceğini öne sürmüşlerdir (9). Sonuçlarımız bu çalışmalara benzer bulunmuştur. Sepsis, ağır sepsis ve septik şok dönemlerindeki CRP, PCT, Laktat düzeyleri ve SOFA skorları sepsis olmayan döneme göre anlamlı olarak yüksektir (Tablo-4, Tablo-5).

Sepsisin şiddeti ile serum prokalsitonin ve CRP düzeylerinin anlamlı bir korelasyon gösterdiğini bildiren çalışmaların aksine septik şoklu hastalarda sepsis ve ağır sepsisli hastalara göre CRP düzeyinin daha düşük olduğunu ve CRP düzeylerinin hastalığın şiddetini belirleyen bir marker olamayacağını öne süren çalışmalar da vardır $(10,11)$. Sonuçlarımız CRP düzeylerinin hem sepsisin tanı aşamasında hem de sepsis durumu ağırlaştıkça yükseldiğini göstermektedir (Tablo-2, Tablo-4).

Hastaların sepsis olmadığı dönemdeki PCT düzeyleri normal referans aralığında bulundu. Bu durum PCT'nin özellikle enfeksiyöz olaylara spesifik olmasıyla açıklanabilir. Sepsisli olmayan hastalarda CRP düzeyinin ortalama değeri ise referans aralığına göre yüksek $(2,6 \mathrm{mg} / \mathrm{dl})$ bulunmuştur. Bu durum yoğun bakımda izlenen hastalarda birçok inflamatuar sürecin olmasına ve CRP'nin inflamatuar olaylarda yükselen nonspesifik bir belirteç olması ile açıklanabilir. $\mathrm{Bu}$ sonuçlar Sümer ve arkadaşlarının (6) çalışmalarıyla uyumludur. Çalışmamızda da septik şok grubunda ölçülen CRP düzeyleri sepsisin diğer evreleri ve sepsisi olmayan hastalara göre daha yüksek bulundu (Tablo-4).

Eksitus olan gruptaki hastaların yoğun bakıma kabul edildiğinde ilk ölçülen ortalama CRP düzeyi 9,06 mg/dl; eksitus olmayan gruptaki hastaların ilk ölçülen ortalama CRP düzeyi 10,14 mg/dl olarak bulunmuştur. Yoğun bakıma yatışta ilk ölçülen CRP düzeylerinin prognozu belirlemede anlamlı olmadığı şeklinde yorumlanabileceği kanısındayız. Ancak yatış boyunca son ölçülen değer ve son ölçülen değerinin ilk ölçülen değere oranının hasta prognozunu belirleme açısından istatistiksel olarak anlamlı olduğu görülmektedir (Tablo-3).

Sepsisde prognozun incelendiği çalışmaların genelinden farklı olarak sepsis evrelerindeki CRP, PCT düzeylerindeki değişimlerinin incelendiği çalışmamızda, sepsis evresinin derecesi yükseldikçe $\mathrm{PCT}$ düzeylerinde yükselme görüldü. Ayrıca hastaların PCT düzeylerindeki değişimler incelendiğinde 6 grupta da istatistiksel anlamlı değişme olduğu görüldü (Tablo-4, Tablo-5).

Laktat düzeyi yüksekliğinin sepsiste hücresel disfonksiyonunun bir yansıması olması nedeniyle hastalığın ciddiyeti ve mortalitenin göstergesi olan bir belirteç olduğu bilinmektedir $(12,13)$. Laktat düzeylerinin ağır sepsis ve septik şok döneminde sepsis olmayan döneme göre anlamlı olarak yüksek olduğu görüldü (Tablo-4, Tablo-5). Laktik asidoz, septik şok sırasında da perfüzyonun yetersiz olduğunun veya anaerobik metabolizma geliştiğinin en iyi göstergelerinden biridir. Bu nedenle laktat düzeyi daha çok organ disfonksiyonunun saptanması için kullanılan bir parametredir. Sepsis, ağır sepsis ve septik şokta hipoperfüzyona bağlı yetersiz doku oksijenizasyonunu değerlendirmede $\geq 4 \mathrm{mmol} / \mathrm{tt}$ değerleri tanısal olarak anlamlı olduğu ileri sürülmektedir. (6).

Çalışmamızda laktat düzeyi ve SOFA skorunun sepsis ve evreleri değerlendirildiğinde istatistiksel olarak anlamlı artış gösterdiği görülmektedir.

Sepsisin ciddiyetinin artışı ile birlikte CRP, PCT, Laktat düzeyleri ve SOFA skoru değişimlerinin değerlendirilmesi literatürdeki benzer araştırmalardan çalışmamızı farklı kılmaktadır.

\section{Sonuç}

Çalışmamızın sonuçlarında sepsis olmayan grubun CRP düzeylerindeki değişimleri incelendiğinde artış oranları en fazla septik şok tanısı aldıklarında, sonrasında azalan sıra ile ağır sepsis ve sepsise geçişlerde oldu. Sepsisteki hastaların da artış oranları septik şoka geçişte ağır sepsise geçişten daha fazla bulundu. Sepsis tanısında bu biyokimyasal belirteçlerin değişimlerin prognositik olarak önemli olabileceği kanısına varıldı.

Çıkar çatışması: Yazarlar çıkar çatışması beyan etmemişlerdir. 


\section{Kaynaklar}

1. Singer M, Deutschman CS, Seymour CW et al The Third International Consensus Definitions for Sepsis and Septic Shock (Sepsis-3). JAMA 2016; 315 (8): 801-10.

2. Shankar-Hari M, Phillips GS, Levy ML et al. Developing a new definition and assessing new clinical criteria for septic shock: for the Third International Consensus Definitions for Sepsis and Septic Shock (Sepsis-3). JAMA 2016; 315 (8): 775-87.

3. Seymour CW, Liu VX, Lwashyna TJ et al Assessment of clinical criteria for sepsis: for the Third International Consensus Definitions for Sepsis and Septic Shock (Sepsis-3). JAMA 2016; 315 (8): 762-74.

4. Rhodes A, Evans LE, Alhazzani W, Levy MM, Antonelli M, Ferrer R et al: Surviving Sepsis Campaign: International Guidelines for Management of Sepsis and Septic Shock: 2016. Crit Care Med. $2017 ; 45$ (3): 486 552.

5. Dupuy AM, Philippart F, Péan Y, et al. Role of biomarkers in the management of antibiotic therapy: an expert panel review: I- currently available biomarkers for clinical use in acute infections.Ann Intensive Care. 2013; 3 (1): 22 .

6. Sümer Ş, Erayman İ, Arıbaş Türk E. Sepsisin erken tanısı ve takibinde prokalsitonin, CRP, IL-6, IL-8 ve endotoksinin rolü.Türk Mikrobiyol Cem Derg.2010; 40 (1): 27-36.

7. Arslan A. at al. Sepsisli yaşlı hastalarda mortaliteyi belirlemede sistatin-C ve pro-BNP'nin etkisi Gaziantep Med J 2014; 20 (1): 47-51.

8. Aks M, Mehta AA, James P. Predictors of mortality of severe sepsis among adult patients in the medical Intensive Care Unit. Lung India 2017; 34 (4): 330-35.

9. Shukeri WFWM, Ralib AM, Abdulah NZ, Mat-Nor MB. Sepsis mortality score for the prediction of mortality in septic patients. J Crit Care. 2018 Feb; 43: 163-68.

10. Müller B, Becker KL, Schachinger $\mathrm{H}$, et al. Calcitonin precursors are reliable markers of sepsis in a medical intensive care unit. Crit Care Med 2000; 28 (4): 977-83.

11. Suprin E, Camus C, Gacovin A, et al. Procalcitonin: a valuable indicator of infection in a medical ICU Intensive Care Med 2000; 26 (9) 1232-8.

12. Kraut JA, Madias NE. Lactic acidosis. N Engl J Med. 2014; 371 (24): 2309-19.

13. Casserly B, Phillips GS, Schorr C, et al. Lactate measurements in sepsis-induced tissue hypoperfusion: results from the Surviving Sepsis Campaign database. Crit Care Med. 2015; 43 (3): 567- 73. 